Women and gender stereotyping in higher education: A case study of Vidyasagar University post-graduates

Dandapat, Asis Kumar $\triangle$

Vidyasagar Teacher's Training College, West Bengal, India (akdmid@yahoo.co.in)

Sengupta, Debjani

University of Calcutta, West Bengal, India (reeang@ rediffmail.com)

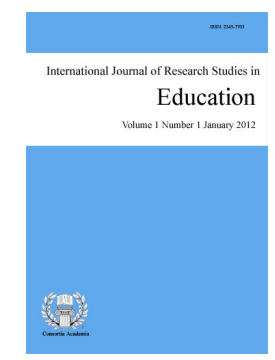

ISSN: $2243-7703$ Online ISSN: 2243-7711

OPEN ACCESS

\begin{abstract}
Based on the responses to four Semi-structured interview schedules and one check list of 400 post-graduate students in Vidyasagar University in West Bengal, this article investigates the influence of gender stereotyping on women's higher education. Several indicators are considered and investigated using non-parametric technique. Given the overall patriarchal structure of Indian society, the results indicate that higher education system is not sufficient itself for developing the right attitudes among today's young adults that needed to succeed in a democratic country-where human dignity is respected.
\end{abstract}

Keywords: gender stereotypes; gendered division of labor; traits; self-concepts; case study 


\section{Women and gender stereotyping in higher education: A case study of Vidyasagar University post-graduates}

\section{Introduction}

Gender disparity in education is an age old phenomenon. Traditionally, girls have been at a disadvantage in most parts of the globe and they continue to be so even today (Jha \& Kelleher, 2006).Eliminating differences in education between men and women has been a priority of development organizations and the international community for many years (Ganguli et al. 2011). The Millennium Development Goal (MDG) targeting to "eliminate gender disparity in primary and secondary education, preferably by 2005, and in all levels of education no later than 2015" is echoed by the United Nations and the World Bank (Ganguli et al. 2011). Need for equality of educational opportunities between men and women on the basis of merit has also been acknowledged in the Universal Declaration of Human rights (UNESCO, 2001). It has been suggested in the literature that educating girls and achieving the MDG goal on gender equity will lead to a range of improved outcomes for developing countries (Schultz, 2002), including higher economic growth (Abu-Ghaida \& Klasen, 2004).

The gender gap in education is more pronounced in poorer countries like South Asia and Sub-Saharan Africa (Singla, 2006). India alone has 40 per cent of the global gender lag in education. Enrolment of women in higher education in India though showing marked improvement since fifties is still lagging behind that of their male counterparts. The share of girls' enrolment in total higher education enrolment rose from a meager 10 per cent in 1950-51 to 38.3 per cent in 2005-06 (MHRD, GOI). Traditionally, not only women are less likely to continue higher education but also disproportionately registered for biological and non-quantitative social sciences as compared to mathematics and pure sciences (Chanana, 2004; Chakraborty, 2009; Dandapat \& Sengupta, 2012). The under-representation of women students in science and technology is an international policy concern as well (Bebbington, 2002).

The disciplinary choices of women have been the focus of debate in the feminist discourse on education and gender (Chanana, 2004). Much has been written on the patriarchal imprint on the disciplinary choices of women in higher education and on the feminine and masculine dichotomy of disciplines (Acker, 1990; Thomas, 1994). Since masculinity and femininity are social constructions (Kellner, 1997) the underlying assumptions about subject or disciplinary choices have to be uncovered along with their close connection to women's place in society (Harding, 1986).

Indian students are nurtured in a society where the lower status of women is normative. Continual exposure to strongly differentiated gender roles is likely to shape student's beliefs about how well males and females perform across a variety of domains. Gender roles are defined by behaviors, but gender stereotypes are beliefs and attitudes about masculinity and femininity (Brannon, 2004). Gender stereotypes are very influential; they affect conceptualizations of women and men and establish social categories for gender. These categories provide not only descriptions of how people think about women and men but also descriptions about what women and men should be, and even when beliefs vary from reality, the beliefs can be very powerful forces in judgments of self and others which means that gender stereotyping places limits on what traits and behaviors are allowed (Prentice \& Carranza, 2002). Therefore, the history, structure, and function of stereotypes are important topics in understanding the impact of gender on people's lives.

Gender stereotypes may have positive or negative effects. Negative gender stereotypes endorsement systematically robbed of women's confidence to think and learn without fear of failure; they are subsequently paralyzed by their own low self-image. It is said that women do three-fifths of the world's work, earn one-tenth of the world's income and own one-hundredth of the world's assets (Ramachandran, 2002). Women's work - 
Women and gender stereotyping in higher education: A case study of Vidyasagar University post-graduates

especially in the home and in a range of informal sector home based work - is invisible. As a result their contribution does not show up in national statistics. They are denied access to information and alienated from decision-making processes (The Hindu, 7 August 2011). Even when they relate to government schemes, they do so as passive recipients. Victimised by age old beliefs that purport to address their health, education, and employment needs, they are forced to view their environment with fear and suspicion.

The content of gender stereotypes may be analyzed into four separate components that people use to differentiate male from female - traits, behaviors, physical characteristics, and occupations (Deaux \& Lewis, 1984) as represented in the following figure.

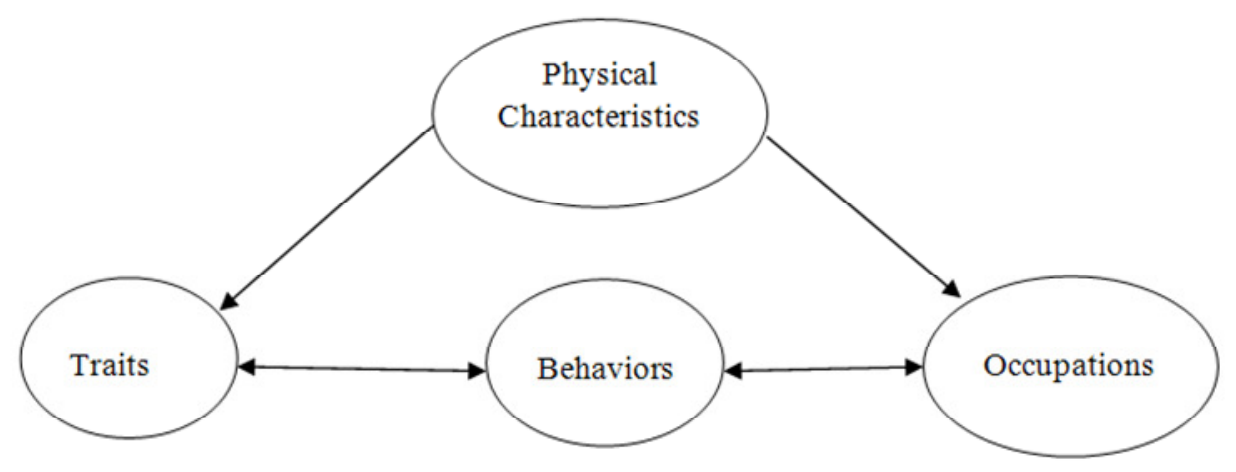

Figure 1. Components of Deaux and Lewis's Model of Gender Stereotyping

Source: Brannon, L. (2004). Gender stereotypes: Masculinity and femininity in Linda Brannon (Ed.), Gender: Psychological perspectives (p. 170).

Each aspect may vary independently, but people make judgments about one based on information about another, to form an interdependent network of associations. People use this network of information in making deductions about gender-related characteristics.

\subsection{Objectives}

The primary goal of this study is to examine university students' beliefs about non- discriminatory performance standard of perception about gender stereotypical behaviors, traits and norms. Research with Western samples indicates that student's educational and occupational outcomes are shaped in part by cultural stereotypes about differences in boys' and girls' competence in various academic domains (Colley \& Comber, 2003; Nosek et al., 2009). Stereotypes shape motivation and performance through several mechanisms, one of which is their influence on self-concept. A second goal of this study was to investigate gender differences in students' self-concepts.

\subsection{Context}

The literature on the determinants of educational attainments has mainly focused on enrolment and primary education. Generally employing limited dependent regression models, studies have identified factors like family income or wealth, parental education, empowerment and education of mother, credit constraints, family size, caste affiliations, place of residence and educational infrastructure as determinants of enrolment and primary school completion rates (Akhtar, 1996; Deolalikar, 1997; Tansel, 1998; Brown \& Park, 2002; Connelly \& Zheng, 2003; Boissiere, 2004; Desai \& Kulkarni, 2008). These studies have also found the presence of strong gender differences.In India, education of girls has historically lagged behind that of boys (Aggarwal, 1987; Agrawal \& Aggarwal, 1994). In addition studies have shown that certain communities and classes fare much worse than the others (Sundaram, 2007). 
Unfortunately, gender disparities at higher levels of education have been limited studies in the Indian context. Vaid's (2004) analysis of trends in gender discrimination across the schooling career of children finds that transition probabilities of girls increase, relative to that of boys, at higher levels of education. Chakraborty (2009) found household economic status; educational profile and gender of the household head, potential cost of schooling, family composition in terms of the number of children and distance are the important determinants of higher education and participation in certain subjects similar to a study of Chanana (2004). Ghosh (2007) considered that 'perceptions of improved employment prospects' are also important determinant for accessing higher education. Sundaram's study (2007) of higher education focuses on disparities across social castes, but ignores gender dimensions. Thorat (2006) observed gender differences in access to higher education. But none of these works have examined that gender stereotyping as an important determinant factor for accessing higher education. Overall, studies have tended to neglect the study of gender stereotyping at higher levels of education in Indian context. This lacuna acts as the motive for the present study.

\section{Methodology}

\subsection{Data collection}

The sample for the study was 400 post-graduates (mean age 23 years), with equal number of males and females, studying in Vidyasagar University in West Bengal. It was selected by stratified sampling technique from the Arts (240), Science (120) and Commerce (40) faculties.

\subsection{Instruments}

The research instruments used for this study were four semi-structure interview schedules and one check-list developed by National Council for Teacher Education (NCTE, 2003) under the aegis of National Human Rights Commission (NHRC) on the basis of gender discrimination questionnaire. The respondents were interviewed on - (1) utility of girls' education, (2) access to resources, (3) Sharing of household responsibilities and (4) professions suitable for girls on different occasions. The check-list was used to get gendered views on personality traits.

\subsection{Procedure}

The participants were approached personally and after establishing rapport interview procedure was conducted on a one to one basis throughout the year 2008-2010. The interview schedule was divided into two parts-one part deals with male and female post-graduate students' perception about utility of girls' education and the other part deals with beliefs and attitudes about behaviors, occupations and traits of men and women in our society. During interviews, the students were requested to give justify their answers so that to get an in-depth picture of their thought process.

\subsection{Data analysis}

Percentage, non-parametric test $\left(\chi^{2}\right)$ and participants' dialogs have been used for the analysis of the data.

\subsection{Limitation of the study}

This study took a first step in this direction, but needs to be supplemented by further research. Generalizations of these findings to other universities have to be made with cautious as it is a case study approach.

\section{Results and discussion}

Analysis has been divided into two sections. Section I deals with male and female post-graduate students 
Women and gender stereotyping in higher education: A case study of Vidyasagar University post-graduates perception about utility of girls' education. Section II shall deals with beliefs and attitudes of post-graduate students about behaviors, occupations, and traits of men and women in our society.

\subsection{Utility of girls' education}

Perception of something is the way that anybody conceives about it or recognizes it using own senses (Ganguly, 2006). Perception has been considered as the phenomenon understanding the personal autonomy which refers here to a student's sense of self-determination, of being able to make choices regarding the direction of his or her actions. It is likely that student's perceptions of utility of girls' education will reflect women's longstanding marginalization from higher education (Solomon, 1985), especially since attitudes and perceptions on any issue are influenced by a variety of historical, social, and cultural factors (e.g., Frank, 2004; Inglehart \& Baker, 2000; Sears, Sidanius, \& Bobo, 2000).

The perception of the importance of girls' education seems to affect enrolments (Bandopadhyay \& Subramanian, 2008) and also subject choices (Bowman \& Hudson, 2006). Evidence has shown that educating women can lead to improved economic and social outcomes (Wolfe \& Zuvekas, 1997). Specifically, recent empirical work, which has mainly focused on developing countries, shows that there are both positive economic consequences and social externalities arising from improving women's education. For example, increases in women's education have been associated with reductions in fertility (Subbarao \& Raney, 1995; Kingdon, 2002; Osili \& Long, 2008), decreases in infant mortality and increases in life expectancy (Behrman \& Deolalikar, 1988; Schutlz, 1993; Dancer et al., 2008), beneficial effects on children's health and nutritional status (Thomas, 1990; Mehrotra, 2006), likely to participate in political meetings (UNESCO, 2000) and greater impact of children's schooling (Filmer, 2006).

As mentioned earlier, this section is concerned with how post-graduate students perceive the utility of girls' education and its relevance which depends very much on their expectations of a student's future role and how education contributes to this role. These expectations seem very much to be rooted in traditional perceptions of gender role ideals which are shown in the following table.

\section{Table 1}

Perception of post-graduate students about utility of girls' education

\begin{tabular}{|c|c|c|c|c|c|c|}
\hline \multirow{2}{*}{ SI } & \multirow{2}{*}{ Statements } & \multicolumn{2}{|c|}{ Agree } & \multicolumn{2}{|c|}{ Disagree } & \multirow{2}{*}{$\chi^{2}$} \\
\hline & & M & $\mathrm{F}$ & M & $\mathrm{F}$ & \\
\hline $\mathrm{i}$ & $\begin{array}{l}\text { develops a positive self -image and confidence } \\
\text { among girls }\end{array}$ & 200 & 200 & $\mathbf{0}$ & $\mathbf{0}$ & \\
\hline ii & prepares girls for economic contribution & 190 & 168 & 10 & 32 & 12.88 \\
\hline iii & $\begin{array}{l}\text { can improve health and nutritional status of children } \\
\text { and other family members }\end{array}$ & 191 & 176 & 9 & 24 & 7.43 \\
\hline iv & will ensure education of future generations & 200 & 200 & $\mathbf{0}$ & $\mathbf{0}$ & \\
\hline $\mathrm{v}$ & will make girls and women aware of their rights & 200 & 200 & $\mathbf{0}$ & $\mathbf{0}$ & \\
\hline vi & $\begin{array}{l}\text { helps raise age at marriage and reduce maternal, } \\
\text { infant, and child mortality }\end{array}$ & 200 & 192 & 0 & 8 & 8.16 \\
\hline vii & helps in reducing the family size & 186 & 200 & 14 & 0 & 14.51 \\
\hline viii & will prepare girls for leadership roles in society & 169 & 200 & 31 & 0 & 33.60 \\
\hline \multirow[t]{2}{*}{ ix } & $\begin{array}{l}\text { will prepare girls for participation and decision } \\
\text { making process in all walks of life }\end{array}$ & 188 & 200 & 12 & 0 & 12.37 \\
\hline & TOTAL & 1724 & 1736 & 76 & 64 & 1.07 \\
\hline
\end{tabular}

Table 1 shows a total agreement of male and female post-graduates (100\%) to the statements, "develops a positive self -image and confidence among girls", "will ensure education of future generations" and "will make girls and women aware of their rights". But, male and female post-graduates opinions about decision making status of educated women (statements ii, iii, vi, vii, viii, and ix) are significantly different in male and female students at $1 \%$ level of significance. A further probing on these issues yielded the following statements that may explain the 
Dandapat, A. K. \& Sengupta, D.

social dynamics behind the responses.

"Parents are not willing to take a share of daughter's income” (a female participant- FA 56)

"Parents can take a share of daughter's income before marriage. After marriage, husband's family will determine it” (a female participant- FA 117)

“Generally, an old aged person depends on sons" (a male participant-MA 97)

"Education is not sufficient for leadership roles of women in our society" (a male participant-MA 107)

"Women are profoundly dependent on males in every sphere of life" (a male participant- MS 14)

However, overall male and female post-graduates opinions about utility of the girls are not significantly different both at $5 \%$ and $1 \%$ level of significance (chi-square $=1.07, p<.05$ ). $96 \%$ of the responses are associated with agreement about utility of the girls' education and it is noted that number of the responses in agree category is higher in females than males. Hence, both male and female post-graduates perceive the utility of girls' education. This result is similar to the study of Bowman and Hudson (2006).

\subsection{Beliefs of post-graduate students}

The distinction between traditional beliefs and beliefs concerning equal opportunity and equal power might apply to all cultures, but the specifics of what constitutes traditionalistic vary. The division of activities and behaviors into male and female domains is universal, without worldwide agreement about what those activities and characteristics are. Such divisions of activities, however, form the basis for gender roles and furnish the potential for gender stereotyping.

The second section of the analysis deals with post-graduate students' perceptions about how women and men think of themselves and how they evaluate their own behaviors, occupations and traits as well as the behaviors, occupations and traits of other i.e. gender stereotyping. Gender inequality in education is not one homogeneous phenomenon, but a collection of disparate and interlinked problems (Sen, 2001). The role of women is a function of three major forces - social institutions, women's access to resources, and the abilities (Morrisson \& Jutting, 2005; Sen, 2001; World Bank, 2001). The core idea behind this framework is that the role of women in developing countries is heavily influenced by social institutions, the key important factor for gender inequality (World Bank, 2001) which includes social norms, codes of conduct, informal laws and traditions. Social institutions may impose direct constraints on women's activities, for instance, by not allowing them to start their own businesses. They might also impose indirect constraints to women via a limited access to resources that are essential to join the labor market in particular health and education (Morrisson \& Jutting, 2005) and the level of abilities which includes issues as psychological obstacles or lack of social support (Jacobs, 1996). Table 2 depicts male and female post-graduates' perceptions about typical behaviors of men and women to reveal the situation of women in our society.

Now, women's access to resources also influences their economic role. Women with better education and access to health care as well as to the labor market will be more likely to get wage employment or highly qualified jobs than those excluded from these resources (Morrisson \& jutting, 2005). Equal education, equal amount of food, equal health and medical care, similar occupations and equal wages constitute the data set for access to resources. From table 2, it is evident that $89.1 \%$ of male and $95.1 \%$ of female respondents agreed about equal access to resources. The disagreement portion arises mainly from two components, 'both can have similar occupations' and 'both need equal amount of food'. Here, $6 \%$ of male post-graduates think that girls and boys do not need equal education. It is consistent with our earlier observations that $4 \%$ of males disagree to utility of girls' education. $17 \%$ of male post-graduates and $4 \%$ of females do not think that both need equal amount of food. The following statement from in-depth interview emerged from respondents: 
Women and gender stereotyping in higher education: A case study of Vidyasagar University post-graduates

"Male and female need not equal amount of food, because biologically they need different amount of calorie" (a male respondent-MS 21)

However, asking the details of women's food intake, it emerges:

"I do not know exactly what a female member in my family eats. But there is somehow an arrangement of food in the house" (a male respondent-MA 53)

Table 2

Post-graduate students' attitude towards the following behaviors

\begin{tabular}{|c|c|c|c|c|c|}
\hline \multirow{2}{*}{ Items } & \multicolumn{2}{|c|}{ Agree } & \multicolumn{2}{|c|}{ Disagree } & \multirow{2}{*}{$\chi^{2}$} \\
\hline & M & $\mathrm{F}$ & M & $\mathrm{F}$ & \\
\hline \multicolumn{6}{|l|}{ Access to resources } \\
\hline Girls and boys need equal education & 188 & 200 & 12 & 0 & \\
\hline Both need equal amount of food & 166 & 192 & 34 & 8 & \\
\hline $\begin{array}{l}\text { Both need to be given equal health care and medical } \\
\text { attention }\end{array}$ & 200 & 200 & 0 & 0 & \\
\hline Both can have similar occupations & 151 & 167 & 49 & 33 & \\
\hline Men and women should be paid equal wages for equal work & 186 & 192 & 14 & 8 & \\
\hline TOTAL & 891 & 951 & 109 & 49 & 18 \\
\hline \multicolumn{6}{|l|}{ Social institutions } \\
\hline Both should be given the same freedom & 168 & 162 & 32 & 38 & \\
\hline Both should be given equal time to play & 189 & 192 & 11 & 8 & \\
\hline Both can be assigned same duties /responsibilities & 69 & 133 & 131 & 67 & \\
\hline Husband and wife should take all decisions jointly & 200 & 200 & 0 & 0 & \\
\hline Household work must be shared by all members & 200 & 200 & 0 & 0 & \\
\hline $\begin{array}{l}\text { Assets should be registered in joint names of husband and } \\
\text { wife }\end{array}$ & 165 & 192 & 35 & 8 & \\
\hline equal share for daughters and sons in family properly/assets & 189 & 200 & 11 & 0 & \\
\hline TOTAL & 1180 & 1279 & 220 & 121 & 3.5 \\
\hline \multicolumn{6}{|l|}{ Level of abilities } \\
\hline Both can perform all tasks equally well & 31 & 86 & 169 & 114 & \\
\hline Both have similar intelligence and abilities & 82 & 124 & 118 & 76 & \\
\hline TOTAL & 113 & 210 & 287 & 190 & 11.76 \\
\hline
\end{tabular}

A new Study report also supports this by stating that the nutrition advantage girls have over boys in the first few months of life seems to be reversed over time as they grow older (The Hindu, 1 January 2012). "Women are eating last, the least and the left over. Nourishing and balanced diet is as a male prerogative. Daughters and brides kept on starvation diet. Food secured middle-aged women as honorary men" (Patel, 2006). Males and females give $100 \%$ agreement about 'both needs to be given equal health care and medical attention'. Though male and female opinions about access to resources are significantly different (as chi-square is 28.08 at 1 degrees of freedom), 96\% responses are associated with agreement to women's equal access to resources.

Social institutions aggregate seven different variables in all. It includes the right to freedom, the right to profession, the right to share of household responsibilities and the right of ownership. All these variables have an economic impact. If women cannot move around or own property in their own names or cannot have a decision making power or have unequal household division of labor, they cannot gain economic independence. But an independent income of women increased their self-reliance, reduced their dependency on household income and helped them to stand on their own feet (Kabeer \& Mahmud, 2004; Morrisson \& Jutting, 2005) and also an important factor for development (Sen, 1999; Kabeer, 1999). Sen (1999) argues that the goal of development is not to achieve a certain set of indicators, but to increase choices (and thereby 'freedoms'). It is evident from the table 2 that about $84.3 \%$ of males and $93.4 \%$ of females agreed about equality of social opportunities between male and female. However, in overall, males and females opinion are not significantly different (Chi square $=3.5, p>0.01)$.

A closer look into the variables of social institutions listed above indicates that the difference between male 
and female opinions lies mainly on the assigning same duties/responsibilities, on the distributing ownership of property/assets rights and on the same freedom to women. In respect of gender inequality in ownership rights and gender inequality in profession (i.e. duties and responsibilities) (Sen.2001), we observe that males are more conservative than females. However, it is argued here that the gender gap in the ownership and control of property is the single most critical contributor to the gender gap in economic well being, social status and empowerment (Agarwal, 1993). On the other hand, males and females are totally agreed (100\%) about equal sharing of household responsibilities.

Following are the participants' remarks relating to social institutions aspect:

Men and women cannot be assigned same duties/ responsibilities due to women's social commitment towards family roles and physical strength. Moreover, both should not be given the same freedom because it is not permitted by the society (a female participant- FA 23)

Men and women cannot be assigned same duties/ responsibilities due to their physical and mental abilities and also, social barriers. Moreover, assets of the family should not be registered in joint names of husband and wife as husband is the main money provider in the family (a male participant-MA 51)

Both cannot be assigned same duties/ responsibilities because women are not aware about outside world. Moreover, both should not be given the same freedom because it will increase social crime (a male participant-MS 57)

Both cannot be assigned same duties/ responsibilities due to the lack of self-confidence among women and also, present unfavorable infrastructure of our society (a male participant-MS 31)

Equal share for daughters and sons in family property/assets is not desirable because a family have to give dowry at the time of marriage of a daughter (a male participant-MA 83)

These perspectives demonstrate the social construction of female and male roles that are performed according to existing social norms. Most men and women seem to fully accept the gender stereotyping behavior of the distribution of rights and responsibilities between sexes. However, women participants are more liberal than men.

The level of abilities includes two components 'Both can perform all tasks equally well' and 'Both have similar intelligence and abilities'. Overall, $72 \%$ males have the opinions that females are psychologically inferior and $48 \%$ of females support it. Scrutinizing the distribution of the students according to two categories given in table 2 ,we find that $85 \%$ of male respondents and $57 \%$ of female students responses that both cannot perform all tasks equally well, whereas, $59 \%$ of male respondents and $38 \%$ of female respondents opined that both have not similar intelligence and abilities. Statistically, male and female post-graduates opinions about ability difference across gender are significantly different as chi-square value is at $1 \%$ level of significance. Responses from interviewees precisely illustrate this pattern, is evident here:

"I strongly believe that males have more intelligence than females. I also think that I have lack of confidence and feels fear when I want to express myself properly. For this reason, I believe that both males and females cannot perform all tasks equally well" (a female participant-FC 11)

"I believe that males have more intelligence than females. I also think that lack of confidence is a major barrier for females' education and performing other tasks also" (a female participant-FA 47)

"Males have more intelligence than females and have the ability of divergent thinking and can do the same work in a different manner" (a female participant-FA 23) 
Women and gender stereotyping in higher education: A case study of Vidyasagar University post-graduates

"A man has better ability than a woman" (a male participant-MC 17)

"Male members are more effective than female members" (a male participant-MS 47)

Clearly, the above participants attributed lack of confidence and low self-esteem among women as one of the factors that contribute to the persistent under-representation of women in the educational fields and other unequal spheres in our society also. This is to be noted that some of these female respondents are university toppers in subjects like Physics or mathematics. These students show, with concern, how deeply gender stereotyping has ingrained into the young minds, even being the most efficient performer at the tertiary level of education. The authors believe that this is the most significant part of this work. Female post-graduates generally reported a lower "self-concept" regarding their abilities and male opinions are more conservative than female ones. These results suggest that access to human capital is more difficult for women in societies where they are considered "inferior". However, women are not inferior to men in their intellectual and physical capacities (Kemal, 1867).Moreover, psychological research on male and female abilities in mathematics and science shows that there are no differences in overall aptitude for these subjects (Spelke, 2005). "Girls are not only tended to attain higher scores than boys, they were also more aware of strategies for understanding, remembering and summarizing information (PISA, 2009; The Hindu, 16 January 2012).

Often there are fundamental inequalities in gender relations within the family or the household. This can take many different forms. Even in cases where there are no overt signs of gender biases, family arrangements can be quite unequal in terms of the sharing the burden of housework and childcare (Sen, 2001). It is quite common in many societies to take for granted that men will naturally work outside the home, while women could do so if and only if they could combine such work with various inescapable and unequally shared household duties (Benin \& Edwards, 1990; Brannen, 1995; Gill, 1998; McHale et al., 1990; White \& Brinkerhoff, 1981; Sen, 2001). This is sometimes called "division of labor", though it often appears as "accumulation of labor" (Sen, 2001). The reach of this inequality includes not only unequal relations within the family, but also derivative inequalities in employment and recognition in the outside world. The - often unequal - division of work among adults in the household is central to the construction of gender within the family (Fenstermaker Berk, 1985; Hochshild \& Machung, 1989). If housework is also perceived of as a gendered activity among children, the likelihood is great that an unequal division of work will be reproduced among them (Evertsson, 2006). Segregation is conceptualized and measured as the difference in two groups' percentage distributions across some set of categories (Reskin \& Bielby, 2005). The attitudes of post-graduate students towards gender equality in sharing housework are presented in the Table 3 after collecting the information from the statement, 'if you have a son and a daughter, both about the same age and ability, who would you ask to do the following?'

Table 3

Post-graduate students' opinions about gendered division of work

\begin{tabular}{|c|c|c|c|c|c|c|c|}
\hline \multirow[b]{2}{*}{ Items } & \multicolumn{3}{|c|}{ Male opinions } & \multicolumn{3}{|c|}{ Female opinions } & \multirow{2}{*}{$\chi^{2}$} \\
\hline & Girl & Boy & Either & Girl & Boy & Either & \\
\hline Housework (outside) & $20(2.5)$ & $497(62)$ & $283(35.5)$ & $8(1)$ & $424(53)$ & $368(46)$ & 22.02 \\
\hline Housework (inside) & $539(45)$ & $10(1)$ & $651(54)$ & $488(41)$ & $16(1)$ & $696(58)$ & 2.71 \\
\hline
\end{tabular}

It can be observed from table 3, $62 \%$ of male post-graduates and $53 \%$ of female post-graduates responded that housework (outside) is for males only. Again, $35.5 \%$ of male it and $46 \%$ of female respondents say either of the sexes can do it. The observed difference between male and female post-graduates opinion about gendered division of labor (housework outside) is found significant $\left(\chi^{2}=22.02\right.$ at 2 degrees of freedom, $p$-value> .05). On the other hand, in the case of housework (inside), it is found that $45 \%$ of the male and $41 \%$ of female respondents felt that housework (inside) is to be done only by females only, whereas, $54 \%$ of the male respondents and $58 \%$ of female respondents say that homework inside can be done by either one. The computed chi-square value $\left(\chi^{2}=^{2.71} p\right.$-value $\left.>.05\right)$ failed to show the significance of the relationship between male and female post-graduates opinion about gendered division of labor (housework inside). This indicates that both male 
and female students endorse housework (outside) for males and housework (inside) for females, but male respondents exhibit more stringent gender stereotyping than females.

When questioned about household work, the manner in which women describe their roles and responsibilities does not differ from men's descriptions of the same. According to participant discourse, women are predominantly grounded in domestic sphere. As Dorsey (1996) explains, "from an early age, daughters are groomed for their marriage roles of wife, mother and food provider... and they are conditioned from an early age to believe that a woman is inferior to a man and that her place is in the home". One female interview participant said the following about housework:

"Generally, girls are not given much time and attention in education due to their excessive engagement in domestic work" (FS - 8)

Another female interviewee expressed her more attachment to housework:

"Girls often contribute wherever needed and carry out self-, as well as family-care work, whereas boys find it easier to skip family-care work" (FA - 3)

Another male interview mentioned that,

"Girls often experience a significantly heavier housework burden than do boys" (MA-16)

In-depth probing revealed that boys had more time to spare than their sisters and did not help their mothers or sisters with household chores. These perspectives demonstrate the social construction of female and male roles that are performed according to existing social norms.

In this connection, a point should be noted that both male and female respondents agreed (100\%) earlier to the sharing of household responsibilities. Here, we observe that 1998 responses (about 50\%) are related with 'either' of the sexes can do the household work which implies that they are negotiating with gender neutral in division of work. However, further probing shows that still there is a division in between 'suitable for males' and 'suitable for females' kind of division in doing household work. A sharp distinction between gender stereotyping awareness (knowing what people in general think about abilities of a typical boy and a typical girl) and gender stereotyping endorsement (people's own personal beliefs about the abilities of a typical boy and a typical girl) exist.

The role of women in modern times is far beyond her home and hearth. She has to take up the dual responsibility of the housewife as well as a professional career which often dictates the choice of profession. The table below represents post-graduate students' perceptions about the following question: Name the three professions that are most suitable for girls in order of preference?

\section{Table 4}

Preferred choice of professions for girls

\begin{tabular}{lcc}
\hline \multicolumn{1}{c}{ Rank } & $\begin{array}{c}\text { Male Respondents } \\
\text { (Number of respondents-200) }\end{array}$ & $\begin{array}{c}\text { Female respondents } \\
\text { (Number of respondents-200) }\end{array}$ \\
\hline First & Teacher (140) & Teacher (190) \\
Second & Cook (80) & Doctor (96) \\
Third & Doctor (70) & Scientist (34) \\
\hline \multicolumn{2}{l}{ Note. Figures in the parenthesis denote sample mean scores where first, second and third choices are valued by '3', '2'and '1'respectively. }
\end{tabular}

This study (Table 4) reveals that females showed a greater interest in teaching than males among the professions 'Lawyer', 'Cook', 'Doctor', 'Architect', 'Tailor', 'Cricketer', 'Teacher', 'Pilot', 'Scientist', 'Surgeon', 'Judge', 'Hockey player', 'Farmer', and 'Mountaineer'. The result is similar to other researches (Francis, 2002; Mendez \& Crowford, 2002; Wahl \& Blackhust, 2000). Male post-graduates rank first three professions for girls as 'Teacher', 'Cook', and 'Doctor', whereas, female post-graduates rank first three 
Women and gender stereotyping in higher education: A case study of Vidyasagar University post-graduates

professions for girls as 'Teacher', 'Doctor', and 'Scientist' among the professional options. Here, also, we observe gender stereotyping beviours as 'teacher', 'cook', and 'doctor' as female domain (Shanti \& Lakshmanasamy, 1999). An interview with the post-graduate students reveals that, according to male and female respondents, teaching is a safe, secured and suitable job to their physical strength and mind, whereas, according to female respondents, it is a better job for females to accommodate their dual roles in the inside as well as outside home because of their flexible timings, long vacations, less strain and relatively low risk factors. The reasons for being a teacher are as under:

"It is better if I get a job even in a primary school" (a female participant-FA 11)

"A female teacher teaches more heartily and they are more responsible" (A male respondent-MA 27)

“A female teacher teaches softly and politely.” (a female participant-FS 23)

"A female has to play dual roles-productive and reproductive. It will be better managed if a teaching post is available" (a female participant-FC 7)

"Most parents are not willing to spend more money for education of women. They are encouraged primarily for family roles and secondarily, for careers" (a female participant-FS 21)

Most of the female respondents are willing to take teaching posts even in primary and secondary school levels and only a few says that they want to get a teaching posts in colleges, universities and professional institutions .This low aspiration again due to gender stereotyping for the females in maintaining dual responsibilities in home and workplace.

The second most appropriate profession for girls as perceived by the male respondents is cook. Though, female respondents did not put it as a preferred profession, $42 \%$ of males have chosen it among the first three professions whose opinion could not go beyond the typical stereotyping of household duties even in the choice of professions.

"Cooking is not easy to do but it is the duty of women"(A male participant-MA 3)

“Women are always enjoying cooking” (A male participant-MS 12)

The other preferred professions as responded by both the male and female respondents are that of doctor and scientists (female respondents only). It is to be noted that whatever may be the magnitude of variation among the male and female responses, the underlying reason for their choices remains the same for all, viz. dominancy of typical feminine traits.

As for example, medical profession is good for women because:

"Females are kind- hearted and soft-minded" (a female participant-FA 11)

“Females do nursing properly with patience” (a male participant MS 52)

These examples are ultimately leading to lower status of females in our society.

Why do women have low self-esteem, lack of self-confidence and lower level of aspirations about future occupations? Does being a woman mean that one is unable to achieve? It is often believed that one's gender identification has a tremendous influence on behavior, perceptions and effectiveness (Capper, 1993). It may be inferred that gender role, which is socially acquired and, in some cases, riddled with stereotypes, influences the perceived capabilities and aspirations of individuals. People use several dimensions to categorize men and women, drawing inferences on one dimension based on information from another. What traits are stereotypically associated with these categories? Studies in the 1960s and 1970s often found evidence for beliefs about the Male 
Dandapat, A. K. \& Sengupta, D.

Gender Role Identity or the Cult of True Womanhood. Recent studies have also found remnants of these beliefs (Lueptow, Garovich-Szabo, \& Lueptow, 2001). The Cult of True Womanhood that arose during Victorian times held that women should be pious, pure, submissive, and domestic. For men, several models of masculinity show gender role stereotypes. One of these is the Male Gender Role Identity, which holds that to be manly, males must identify with the elements of that role, including the need to avoid all feminine activities and interests, have an achievement orientation, suppress emotions, and be aggressive and assertive. In 2010, these beliefs still hold true for the respondents of this study as evidenced from the following table.

Table 5

Male/female opinions about gender identity traits

\begin{tabular}{|c|c|c|c|c|c|}
\hline \multicolumn{2}{|c|}{ Items } & Male trait & Female trait & $\begin{array}{l}\text { Common to } \\
\text { both }\end{array}$ & $\begin{array}{l}\text { Uncorrelated } \\
\text { gender identity }\end{array}$ \\
\hline \multicolumn{2}{|c|}{ Male gender role identity traits } & $1.343(13)$ & $2.280(4)$ & $1.044(64)$ & $0.603(19)$ \\
\hline Give them hell & $\begin{array}{l}\text { Aggressive } \\
\text { Outgoing } \\
\text { Competitive }\end{array}$ & $1.510(13)$ & $49.00(2)$ & $1.060(58)$ & $0.620(27)$ \\
\hline Sturdy & Sturdy & $1.56(65)$ & $1.00(0)$ & $1.14(19)$ & $0.01(16)$ \\
\hline Big wheel & $\begin{array}{l}\text { Dominant } \\
\text { Leader } \\
\text { Ambitious } \\
\text { Career oriented } \\
\text { Money oriented } \\
\text { Self-confident }\end{array}$ & $0.93(6)$ & $2.37(5)$ & $1.04(70)$ & $0.70(19)$ \\
\hline No sissy staff & Independent & $1.08(6)$ & $0.04(3)$ & $1.01(88)$ & $19.00(2)$ \\
\hline \multicolumn{2}{|c|}{ True cult of womanhood traits } & $0.814(1)$ & $1.321(25)$ & $1.035(54)$ & $0.659(20)$ \\
\hline Pious & Religious & $1.00(0)$ & $0.63(16)$ & $1.02(76)$ & $1.92(9)$ \\
\hline Submissive & $\begin{array}{l}\text { Shy } \\
\text { Passive } \\
\text { Dependent } \\
\text { Submissive } \\
\text { Quiet } \\
\text { Gentle } \\
\text { Tender } \\
\text { Tactful } \\
\text { Kind } \\
\text { Helpful } \\
\text { Cooperative } \\
\text { Flexible } \\
\text { Sensitive } \\
\text { Emotional } \\
\text { Easily } \\
\text { discourage } \\
\text { Get hurts easily }\end{array}$ & $0.81(2)$ & $1.48(25)$ & $1.02(50)$ & $0.64(23)$ \\
\hline Domestic & Neat & $1.00(0)$ & $0.57(15)$ & $1.10(85)$ & $1.00(0)$ \\
\hline Purity & Soft spoken & $1.00(0)$ & $0.80(40)$ & $1.17(55)$ & $1.09(6)$ \\
\hline
\end{tabular}

Note. Figures in parenthesis indicate percentage of response.

Table 5 illustrates that male /female opinion about gender identity traits. It depicts that male/female opinions are more or less similar in respect of common traits (i.e. 1.044 for male gender identity traits and 1.035 for true cult of womanhood traits) and uncorrelated with gender identity ( 0.609 for male gender identity traits and 0.659 for true cult of womanhood traits). It is also to be noted that $64 \%$ responses are 'common' to male gender role identity traits and 54\% responses are 'common' with true cult of womanhood traits. It is a good indication for an egalitarian society. However, male /female opinion about male gender identity traits domain and true cult of womanhood traits domain, asking whether it is a male trait or a female trait, differences. In the case of male gender role identity domain, $13 \%$ responses indicated elements associated with male traits and male opinions are larger than female opinions (as m/f opinion is 1.343) for male traits. Give them hell and sturdy component are 
Women and gender stereotyping in higher education: A case study of Vidyasagar University post-graduates

mainly responsible for this. On the other hand, in the case of true cult of womanhood traits domain, $25 \%$ responses indicated elements associated with female traits and again, male opinions are larger than female opinions (as $\mathrm{m} / \mathrm{f}$ opinion is 1.321) for female traits showing larger number of males with gender stereotypes. Submissive component (where $\mathrm{m} / \mathrm{f}$ opinion is 1.48) is mainly responsible for this. A closer look at the submissive component reveals that both male and female post-graduates indentify 'shy', 'passive', 'tender' and 'flexible' as female traits.

Here are some of the extracts from in-depth interviews:

“The terms 'shyness' and 'tender' are associated with girls only, 'emotional', and 'kind' are common category which is influenced by socio-cultural factors of a society. Sometimes, girls do a work, just like a 'blunt'”, (a female participant -FS 8).

"The terms 'shyness', 'tender', 'emotional', are the characteristics of females' candidate only and 'kind' is a characteristic of both male and females and 'Imaginative' is males only" (a female participant-FC 6).

"Girls know little, but show more. Actually they are easily discouraged" (a male participant-MA 14)

“Generally, males are more 'competitive’” (a male participant-MS 21)

"It is desirable from the society that girls should be 'shy' and 'tender' and 'soft spoken"” (a male participant-MC 9).

The dominant interpretation of shyness (submissiveness); that it is rooted in either academic weakness, lack of motivation or a lack of confidence in their capabilities as young women, is culturally negotiated and accepted by both sexes as a quasi-'natural' attribute belonging to females constituting an important part of their 'cultural identity'(Hall,1996).

\section{Conclusion}

Enrolment of women in higher education in India is still lagging behind that of their male counterparts and registered disproportionately for biological and non-quantitative social sciences as compared to mathematics and pure sciences (Chanana, 2004; Chakraborty, 2009; Dandapat \& Sengupta, 2012). There is now a considerable body of knowledge generated by research about the causes and consequences of women's under-representation in science and technology in higher education (Etzkowitz, Kemelgor, \& Uzzi, 2000; European Commission, 2000; Fielding, Glover, \& Smeaton, 1997; Greenwood, 2000; Rose, 1998). Why has education been unequal accessible to women for decades and also confined in traditional fields in West Bengal also? Part of the answer lies on the supply side - there is clearly a lack of adequate and sensitive educational efforts to mobilize women, involve them in the educational process and help them reflect critically on their lives. The other side of the problem lies in women's own inability and lack of will, self-confidence, self-awareness and assertiveness to demand education.

Indeed, gender inequality in higher education is not one homogeneous phenomenon, but a collection of disparate and interlinked problems in our society--inequalities in mortality, natality, basic facility, special opportunity, profession, ownership and household (Sen,2001). The different forms of gender inequality can impose diverse adversities on the lives of men and boys, in addition to those of women and girls. In understanding the different aspects of the evil of gender inequality, we have to look beyond the predicament of women and examine the problems created for men as well by the asymmetric treatment of women (Sen, 2001). Gender inequalities exist because of discrimination in the family and societal institutions and social, cultural, and religious norms that perpetuate stereotypes, practices and beliefs that are detrimental to women. 
The present study attempts to investigate post-graduate students' beliefs and attitudes about behaviors, occupations and traits of men and women in our society to sort out the influence of gender stereotyping on women's higher education and also, to find out whether higher education as an instrument of liberation or servitude. Based on the responses of post-graduate students in Vidyasagar University in West Bengal, this article reveals that 'teaching" jobs are by far the best jobs for females because they find it easier to balance among their multiple roles as mothers, wives and employees. However, most male post-graduates think that 'male and female cannot be assigned same duties /responsibilities' and 'both do not have similar intelligence and abilities'. Nearly half of post-graduate females support it. This analysis also reveals that the age-old notion of gender division of labor still prevails in their mind which has made household management as the main activity of women. This sets the character of women's work outside home as secondary, whereas for men, work outside home, is primarily for livelihood. This study also reveals a sharp contrast between male and female perceptions about the traits and attributes of human being needed for quality of life where human dignity is respected. Both respondents think 'sturdy' as essentially male trait and 'Independent' as common trait. Both male and female respondents think that 'Shy' 'passive' under 'submissiveness' domain is essentially feminine. However, the opinion of post-graduate males is basically conservative and the opinion of post-graduate females is in a dilemma between 'what they want' and 'what will people say'. The authors uphold the need to be free from age-old gender specific social bondage. In the progressive society of tomorrow, life should be joint venture for men and women.

In the earlier analysis we have observed that low self-esteem among the female respondents, perceptions about unequal gendered division of labor and beliefs about social attitudes towards 'freedom' of movement and choices, towards women's intelligence and abilities, professional equality and property rights are major demand-side sources of gender inequality in higher education. Women's access to higher education is very much dependent on their earlier access to education and also, their earlier performance. Performance is influenced by one's perceived competence, by positive expectancies, by one's own strength, and efficacy, and by self-esteem (Bandura, 1986; Benassi, 2001).Negative gender stereotyping endorsement have an impact on students' self-concept---which in turn influences their academic career choices. Low self-esteem among female students is determined by a variety of historical, social, and cultural factors (e.g., Frank, 2004; Inglehart \& Baker, 2000; Sears, Sidanius, \& Bobo, 2000) which again determine gender stereotyping. Hence, low self-esteem produced by gender stereotyping in our society is one of the major causes for women's unequal access to higher education and subject choices. The results of this study is similar to a recent research that stresses cultural and structural factors as the main underlying reasons explaining the lower participation of women in natural sciences; namely, negative gender stereotypes and old-fashioned institutional structures (Sanchez de Madariaga, 2010).

In addition, this study gives an idea in which direction the wind of change is blowing as regards the advancement of higher education for women in West Bengal. Education in general and higher education in particular, is expected to uphold the dignity of women as equal partners in societal development. The principle of equality in a highly stratified society like India rests on changes in the value and normative structure, and the educational system has a pivotal role to play in creating awareness among the more and the less equals of our society in terms of their rights, privileges and duties towards others (Bhat, 1999). Here we observed that the higher education system is not sufficient for developing the right attitude and independent and creative thinking among post-graduate students similar to the results of a recent in-depth Commonwealth Secretariat study (2010) in four countries (India, Malaysia, Seychelles and Trinidad and Tobago); a recent in-depth Commonwealth Secretariat study in four countries (India, Malaysia, Seychelles and Trinidad and Tobago, also confirmed that educational processes can reinforce and strengthen gender stereotypes rather than challenge them. Hence, among other possible measures, it requires gender sensitization of males and females at all levels of society.

Gender stereotyping starts as early as infancy and needs therefore to be tackled in the earliest stages in life. The gender specific roles they observe around them in their families, attitudes, images, school material etc conveys traditional gender roles and stereotypes on what girls and boys "should" be or do, it is likely that they will try to fit as much as possible with this model, hence, by triggering the cycle of inequalities between women 
Women and gender stereotyping in higher education: A case study of Vidyasagar University post-graduates

and men throughout life. A consorted and coordinated action in different areas, including awareness raising of parents, teachers, peer groups and the members of the society, reform of education systems and material and new legislation concerning the media is therefore highly necessary. This requires a reformation of the whole society. Changes in many different levels and the cooperation of all concerned actors will support such a change, but women's own will power at the highest level is central to this change.

\section{References:}

Abu Ghaida, D. \& Stephan, K. (2004). The economic and human development costs of missing the millennium development goal on gender equity. World Bank Working Paper. Report No. 29710.

Acker, J. (1990). Hierarchies, jobs, bodies: A theory of gendered organizations. Gender Sociology, 4, $139-158$. <http://dx.doi.org/10.1177/089124390004002002>

Aggarwal, J. C. (1987). Indian women: Education and status. New Delhi: Arya Book Depot.

Agrawal, S. P., \& Aggarwal, J. C. (1994). Third historical survey of educational development in India: Select documents, 1990-1992. New Delhi: Concept Publishing Company.

Akhtar, S. (1996). Do girls have a higher school drop-out rate than boys? A hazard rate analysis of evidence from a third world city. Urban Studies, 33(1), 49-62. <http://dx.doi.org/10.1080/00420989650012112>

Bandopadhyay, M., \& Subrahmanian, R. (2010). Gender equity in education: A study of trends and factors. Research Monograph No. 18. New Delhi: National University of Education \& Planning.

Bebbington, D. (2002). Women in science, engineering and technology: a review of the issues. Higher Education Quarterly, 56(4), 360-375. <http://dx.doi.org/10.1111/1468-2273.00225>

Boissiere, M. (2004). Determinants of primary education outcomes in developing countries. Background paper for evaluation of the World Bank's support to primary education. Washington DC: The World Bank.

Bowman, N. A., \& Elizabeth, H. (2006). Gender differences and similarities in attitudes toward college access. University of Michigan.

Brannon, L. (2004): Gender: Psychological perspectives. Allyn and Bacon.

Brown, P. H., \& Park, A. (2002). Education and poverty in rural China. Economics of Education Review, 21(6), 523-541. <http://dx.doi.org/10.1016/S0272-7757(01)00040-1>

Chanana, K. (2004). Gender and disciplinary choices: Women in higher education in India. Paper presented at the UNESCO colloquium on research and higher education policy, Paris, 1-3 December.

Chakraborty, A. (2009). Determinants of participation in higher education and choice of disciplines: Evidence from urban and rural Indian youth. South Asia Economic Journal,10(2), 371-402. <http://dx.doi.org/10.1177/139156140901000205>

Desai, S., \& Kulkarni, V. (2008). Changing educational inequalities in India in the context of affirmative action. Demography, 45(2), 245-270. < http://dx.doi.org/10.1353/dem.0.0001>

Dorsey, B. J. (1996). Gender inequalities in education in the Southern African Region: Analysis of intervention strategies. Harare: UNESCO.

Etzkowitz, H., Kemelgor, C., \& Uzzi, B. (2000). Athena unbound the advancement of women in science and technology. Cambridge: Cambridge University Press. <http://dx.doi.org/10.1017/CBO9780511541414>

Evertsson, M. (2006). The reproduction of gender: Housework and attitudes towards gender equality in the home among Swedish boys and girls. The British Journal of Sociology, 57(3), 415-436. $<$ http://dx.doi.org/10.1111/j.1468-4446.2006.00118.x>

Ganguli, I., Hausmann, R., \& Viarengo, M. (2011). The closing of the gender gap in education: Does it foretell the closing of the employment, marriage, and motherhood gaps? Available online at http://web.hks.harvard.edu/publications/getFile.aspx?Id=683

Ghosh, J. (2008). Caste and discrimination in higher education: Evidence from the national sample surveys. Paper presented at the Conference on Affirmative Action in Higher Education in India, the United States and South Africa, New Delhi, March 19-21.

Jacobs, J. A. (1996). Gender inequality and higher education. Annual Review of Sociology, 22, 153-185. $<$ http://dx.doi.org/10.1146/annurev.soc.22.1.153> 
Dandapat, A. K. \& Sengupta, D.

Jha, J., \& Kelleher, F. (2006). Boys' underachievement in education: An exploration in commonwealth countries. London: Commonwealth Secretariat.

Kabeer, N. (1999). Resources, agency, achievements: Reflections on the measurement of women's empowerment. Development and Change, 30(3), 435-464. $<$ http://dx.doi.org/10.1111/1467-7660.00125>

Kabeer, N., \& Mahmud, S. (2004). Globalization, gender and poverty: Bangladesh women workers in export and local market. Journal of International Development, 16, 93-109. < http://dx.doi.org/10.1002/jid.1065>

Kingdon, G. G. (2002). The gender gap in educational attainment in India: How much can be explained ? The Journal of Development Studies, 39(2), 25-53. <http://dx.doi.org/10.1080/00220380412331322741>

Morrisson, C., \& Jutting, J. P. (2005). Women's discrimination in developing countries: A new data Set for better policies. World Development, 33(7), 1065-1081. <http://dx.doi.org/10.1016/j.worlddev.2005.04.002>

Nosek, B. A., Smyth, F. L., Sriram, N., Lindner, N. M., Devos, T., Ayala, A., Bar-Anan, Y., \& et al., (2009). National differences in gender-Science stereotypes predict national sex differences in science and math achievement. Available online at http://www.pnas.org/content/supp1/2009/06/30/0809921106.DCSupplemental

Patel, T. (Ed.) (2006). Sex selective abortion in India- gender, society and new reproductive technologies. Delhi: California \& London: Sage Publications.

Sanchez de Madariaga, I. (2010), Gender in science and technology, ERA 2030. Preparing Europe for a new renaissance Sevilla, Spain. Available online at http://www.erab2010.com/Publico/Programme/_Recursos/Sanchez_de_Madariaga.pdf

Sen, A. (1999). Development as freedom. New York: Knopf.

Sen, A. (2001). Many faces of gender inequality. Frontline 18 (22, Oct. 27-Nov. 9).

Spelke, E. S. (2005). Sex differences in intrinsic aptitude for mathematics and science? A critical review. American Psychologist, 60(9), 950-958. <http://dx.doi.org/10.1037/0003-066X.60.9.950>

Sundaram, K. (2006). On backwardness and fair access to higher education. Economic and Political Weekly, 41(50), 5173-5182.

Thomas, K. (1990). Gender and subject in higher education. Buckingham. The Society for Research into Higher Education and the Open University Press, Acker, Bandra.

Thorat, S. (2006). Higher education in India: Emerging issues related to access, inclusiveness and equity. Nehru Memorial Lecture, University of Mumbai, Mumbai.

World Bank. (2001). Engendering development through gender equality in rights, resources, and voice. Policy Research Report. Washington, D.C. 